\title{
シアノおよびアセチルアセトナト混合配位子コバルト(II) 錯体によるメタクリル酸メチルの重合
}

\author{
(1980 年 5 月 19 日受理)
}

新井義夫・松田 弘喜・浦沢 光 典*

\section{1 緒言}

アセチルアセトナトコバルト（II）錯体を開始剤とするメタクリ ル酸メチル（以下 MMA と略記する）の塊状重合反応では, ポ リメタクリル酸メチル(以下 PMMA と略記する)の収率がきわめ て小さい1。このときに塩化アセチルを添加する2)と PMMA の 収率が増加する。また溶媒中でこの重合反応を行ならと, ジオキ サン中では収率がかなり大きくなる1)が，他の溶媒では小さい。

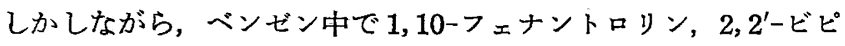
リジン，ピリジンなどを加えると PMMA の収率の増大する こ とが報告されている。一方, シアノコバルト(II)錯体4)およ゙゙シ アノ $\left(2,2^{\prime}\right.$ ービピリジン)コバルト (II) 錯体 ${ }^{5}$ の溶液は, 界面活性剂 と水素の存在下で MMA 重合の開始作用をもつことを高橋らが 報告している。

以上のことから著者らは, アセチルアセトナトのみを配位する コバルト錯体の MMA 重合開始能力は小さいが, さらに他の配 位子を加えて混合配位子錯体にすれば開始能力が高まると考え だ。本報ではアセチルアセトナト（以下 acac と略記する）とシ アノとの混合配位子コバルト（II）錯体の溶液による MMA の重 合反応について検討した結果を報告する。

\section{2 実験}

\section{1 重合反応}

MMA $5 \mathrm{~cm}^{3}$, 水 $5 \mathrm{~cm}^{3}$, および所要量のアセチルアセトン, 界 面活性剤，シアン化カリウムをゴム製セラムキャップ付き $50 \mathrm{~cm}^{3}$ のフラスコに入れた。フラスコを佰温重合槽に取り付け，反応系 内の空気を水素または窒素と置換した。 $5 \mathrm{~cm}^{3}$ の水に溶かした塩 化コバルト（II） $1.5 \times 10^{-4} \mathrm{~mol}$ を注射器を用いてセラムキャップ からフラスコ内に注入した。所要量の酸素ガスを反応器の気相部 へ同様に注入した。フラスコをアルミニウムハクで包んで光をさ

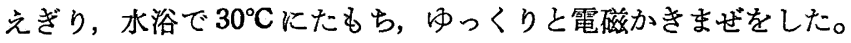
一定時間後, 反応混合物をメタノール中に投入して重合物を沈段

* 北見工業大学工業化学科, 090 北見市公園町

1) Z. Osawa, M. Sorimachi, H. Kanazawa, Y. Ogiwara, J. Polym. Sci., Polym. Chem. Ed., 11, 523(1973).

2）大津隆行，三崎敏一，西川幸利，高分子化学， 29, 718 (1972).

3) K. Kaeriyama, Y. Yamazaki, Bull. Chem. Soc. Jpn., 44, 3099(1971).

4）高橋三視, 飯村一賀, 竹田政民, 工化, 68, 980(1965).

5）高橋三視, 桑原 豊, 竹田政民, 日化, 1973, 814 .
させた。分離した重合物をベンゼンに溶解し，水洗したのちにメ タノール中に投入して再沈殿した。重合物を恒量になるまで室温 で減圧乾燥して重合率を求めた。

\section{2 試薬}

アセチルアセトンは減圧蒸留により精製した。MMA，スチレ ンは常法により精製した。2,2-ジェニルー1ーピクリルヒドラシ ル（以下 DPPH と略記する）は再結晶により精製した。塩化コ バルト(II)六水和物, シアン化カリウムは市販特級品を用いた。 界面活性剂は非イオン性の Tween 80 (ポリ(オキシェチレン)ソ ルビタン=モノオレアート)を用いた。 ベンゼン, メタノールは 再蒸留して用いた。水は蒸留水を沸騰したのち, 窒素雾囲気下で 貯蔵したものを用いた。水素は市販高純度品を用いた。窒素は $400^{\circ} \mathrm{C}$ に加熱した銅網を通して脱酸素したものを用いた。

\section{3 共重合体組成分析法}

スチレンと MMA との共重合体の組成は $\mathrm{C}$ と $\mathrm{H}$ の元素分析值 から計算した。

\section{3 結果と考察}

MMA の重合に対するCo-CN-acac のモル比の影響を調べた 結果を表 1 (A) に示す。acac のみの単一配位子では PMMA が ほとんど生成しない。シアン化カリウムを加えて CN と acac と の混合配位子にすると PMMA の生成が認められた。とくにモル 比が $\mathrm{Co}_{0}: \mathrm{CN}: \mathrm{acac}=1: 3: 2$ (以下この順序で組成比を示す) のときに最高収率を得たので，このモル比の錯体についてさらに 追求した。

1:3:2 の錯体による再実験の結果は, 表 1 (B)に示すように PMMA の収率にバラッキを示した。この原因の一つとして反応 器内の空気を水素または窒素に置換する操作の不完全によること が考えられる。しかし置換操作を慎重に行なうと, 予期に反して 収率が減少する傾向を示した。このことから直換操作の不完全の ために反応容器内に残存した微量の酸素が錯体の重合開始活性に 影響を与えたと推測した。このために反応容器内の空気を水素ま たは窒素に置換する操作を十分に行なったのちに，反応容器内の 気相部分に酸素ガスを注入し，PMMA の収率におよぼす酸素の 影響を調べた。この結果を図 1に示す。ここでよい収率を示した 酸素注入量 $3 \mathrm{~cm}^{3}$ の条件で界面活性剂添加量の影響を調べた。図 2 に示すように, 界面活性剂無添加では PMMA が生成しない が，添加により生成が認められるようになる。添加率が MMAの 重量の 3wt\% 以下では PMMA の収率が小さいが, 4wt\%では 収率が増大した。しかしながら収率にかなりのバラッキが認めら 
Table 1 Polymerization of MMA by cobalt (II) complexes with $\mathrm{CN}$ and acac mixed ligands

(A) Preliminary examination

$\mathrm{Co}($ II $)=1.5 \times 10^{-4} \mathrm{~mol}, \mathrm{MMA}=5 \mathrm{~cm}^{3}$, Solvent $\left(\mathrm{H}_{2} \mathrm{O}\right)$ $=10 \mathrm{~cm}^{3}$, Surfactant (Tween 80$)=4 \mathrm{wt} \%$ (based on the weight of MMA), Reaction temp. $=30^{\circ} \mathrm{C}$, Reaction time $=3 \mathrm{~h}$

\begin{tabular}{ccccc}
$\begin{array}{c}\text { Co : CN : acac } \\
\text { (molar ratio) }\end{array}$ & $\begin{array}{c}\text { Conversion } \\
\text { Under } \\
\text { hydrogen }\end{array}$ & $\begin{array}{c}\text { Under } \\
\text { nitrogen }\end{array}$ \\
\hline 1 & 0 & 1 & trace & 0 \\
1 & 1 & 1 & 1.2 & 2.1 \\
1 & 2 & 1 & 27.6 & 12.3 \\
1 & 3 & 1 & 6.2 & 2.2 \\
1 & 4 & 1 & 2.4 & 4.2 \\
1 & 0 & 2 & 0 & 0 \\
1 & 1 & 2 & 27.5 & 10.1 \\
1 & 2 & 2 & 21.3 & 22.8 \\
1 & 3 & 2 & $80.1^{a)}$ & $79.3^{b)}$ \\
1 & 4 & 2 & 1.8 & 1.9 \\
1 & 0 & 3 & trace & 0 \\
1 & 1 & 3 & 0.9 & 0.7 \\
1 & 2 & 3 & 29.9 & 36.9 \\
1 & 3 & 3 & 5.5 & 29.8 \\
1 & 4 & 3 & 5.2 & 21.2
\end{tabular}

(B) Reexamination
a) 53.9
20.4
b) 31.6

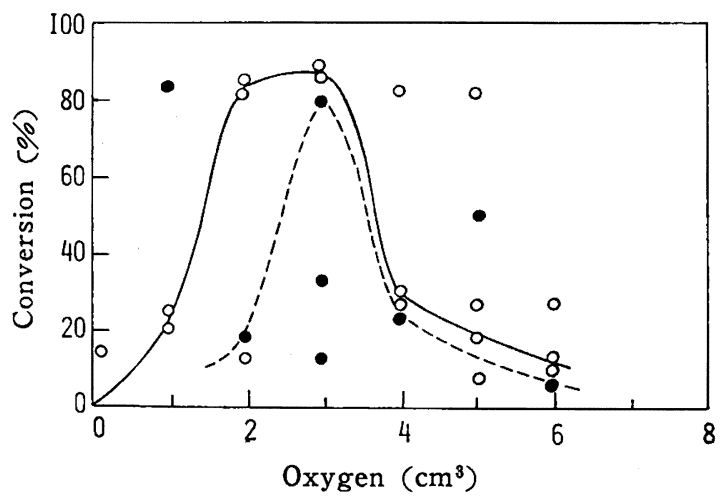

Fig. 1 Effect of addition of oxygen on the polymerization of MMA by cobalt(II) complexes with $\mathrm{CN}$ and acac mixed ligands (No. 1)

$\mathrm{Co}(\mathrm{II})=1.5 \times 10^{-4} \mathrm{~mol}$, Ratio of $\mathrm{Co} / \mathrm{CN} / \mathrm{acac}=1: 3: 2$, MMA $=5 \mathrm{~cm}^{3}, \quad$ Solvent $\left(\mathrm{H}_{2} \mathrm{O}\right)=10 \mathrm{~cm}^{3}$, Surfactant (Tween 80 ) $=4 \mathrm{wt} \%$ (based on the weight of MMA), Reaction temp. $=30^{\circ} \mathrm{C}$, Reaction time $=3 \mathrm{~h}$

Atmosphere -

$$
\text { -O- : Hydrogen, ------ : Nitrogen }
$$

れた。6wt\% 以上では収率のバラッキが小さくなった。これよ りさきの図1で収率にバラッキが認められるのは, 界面活性剂添 加率 (4 wt\%) の不十分に基づくものと思われる。

PMMA 収率のバラッキが小さい界面活性剤添加率 $8 \mathrm{wt} \%$ で 酸素添加量の影響をふたたび調べた。図 3 に示すとおりに水素雾 囲気中, 酸素添加量 $3 \sim 8 \mathrm{~cm}^{3}$ で PMMA の収率が大きく, 図 1 と比較してバラッキの減少が認められた。窒素雾囲気中では, 水

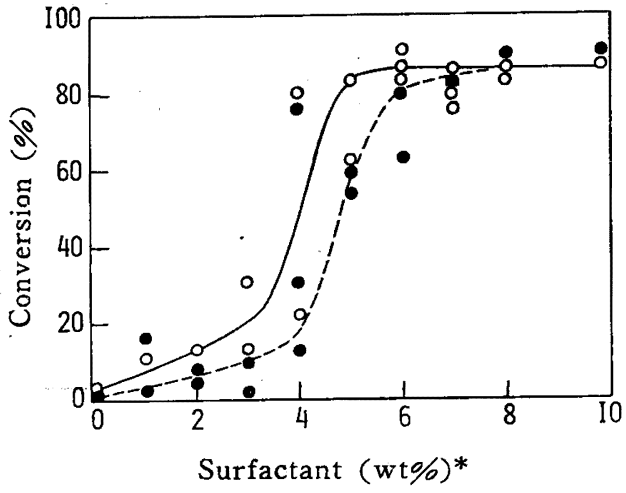

Fig. 2 Effect of the concentration of surfactant on the polymerization of MMA by cobalt(II) complexes with $\mathrm{CN}$ and acac mixed ligands (No. 1)

$\mathrm{Co}(\mathrm{II})=1.5 \times 10^{-4} \mathrm{~mol}$, Ratio of $\mathrm{Co} / \mathrm{CN} / \mathrm{acac}=1: 3: 2$, $M M A=5 \mathrm{~cm}^{3}$, Solvent $\left(\mathrm{H}_{2} \mathrm{O}\right)=10 \mathrm{~cm}^{3}$, Oxygen $=3 \mathrm{~cm}^{3}$,

Reaction temp. $=30^{\circ} \mathrm{C}$, Reaction time $=3 \mathrm{~h}$

* Surfactant $(w t \%)=$ Tween 80 (based on the weight of MMA).

Atmosphere-

-O- : Hydrogen, ----- : Nitrogen

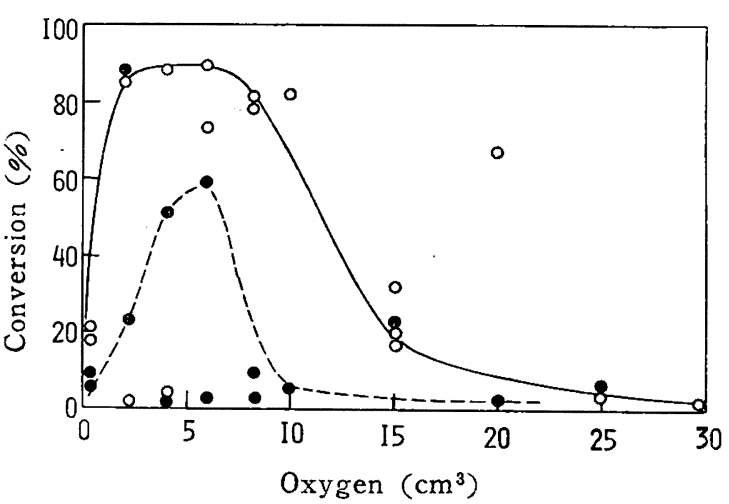

Fig. 3 Effect of addition of oxygen on the polymerization of MMA by cobalt(II) complexes with $\mathrm{CN}$ and acac mixed ligands (No. 2)

$\mathrm{Co}(\mathrm{II})=1.5 \times 10^{-4} \mathrm{~mol}$, Ratio of $\mathrm{Co} / \mathrm{CN} / \mathrm{acac}=1: 3: 2$, MMA $=5 \mathrm{~cm}^{3}$, Solvent $\left(\mathrm{H}_{2} \mathrm{O}\right)=10 \mathrm{~cm}^{3}$, Surfactant (Tween 80 ) $=8 \mathrm{wt} \%$ (based on the weight of MMA),

Reaction temp. $=30^{\circ} \mathrm{C}$, Reaction time $=3 \mathrm{~h}$ Atmosphere-

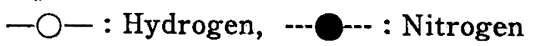

素雾囲気中とくらべて収率が低く, 酸素添加量の有効範囲も狭い。 また過剩の酸素添加は重合反応を抑制した。

図 3 でよい収率を示した水素雾囲気中, 酸素添加量 $4 \mathrm{~cm}^{3}$ の条 件で, 重合速度におよぼす界面活性剂添加率の影響を調べた。図 4 に示すように，界面活性放の添加率が小さいと重合速度が遅い が，大きくするとはやくなり，8wt\% 以上では重合速度に大差 が認められなくなった。

重合反応の形式を確かめるために DPPH の添加効果，および スチレンと MMA の共重合反応を行なった。水素雾囲気下, 界面 活性剂 $8 \mathrm{wt} \%$, 酸素 $4 \mathrm{~cm}^{3}$ 添加の条件では, 1.5 時間の反応で 図 4 に示寸ように約 $80 \%$ の収率が得られるが、コバルトと等モ 


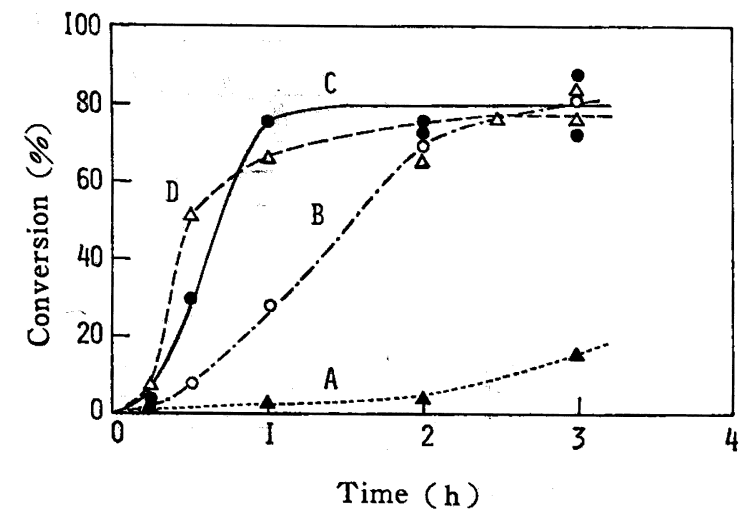

Fig. 4 Effect of the concentration of surfactant on the polymerization of MMA by cobalt(II) complexes with $\mathrm{CN}$ and acac mixed ligands (No.2)

$\mathrm{Co}(\mathrm{II})=1.5 \times 10^{-4} \mathrm{~mol}$, Ratio of $\mathrm{Co} / \mathrm{CN} / \mathrm{acac}=1: 3: 2$, MMA $=5 \mathrm{~cm}^{3}$, Solvent $\left(\mathrm{H}_{2} \mathrm{O}\right)=10 \mathrm{~cm}^{3}$, Oxygen $=4 \mathrm{~cm}^{3}$, Atmosphere $=$ Hydrogen, Reaction temp. $=30^{\circ} \mathrm{C}$ Surfactant (Tween 80)
A - $---: 2 w t \%$ (based on the weight of MMA), B - - O-- : $4 \mathrm{wt} \%, \quad \mathrm{C}-\mathrm{O}-: 8 \mathrm{wt} \%, \quad \mathrm{D}$ $--\triangle--: 12 w t \%$

ルの DPPH を添加して 1.5 時間および 3 時間の反応を行ない, それぞれ 1.3\% および 4.5\% の収率を得た。共重合反応を行な い, 図 5 の組成曲線を得た。重合反応において DPPH の重合の 抑制作用が認められ, 共重合体組成が通常のラジカル共重合の結 果と一致するので，この錯体を開始剤とする重合反応はラジカル 的に進行しているものと思われる。

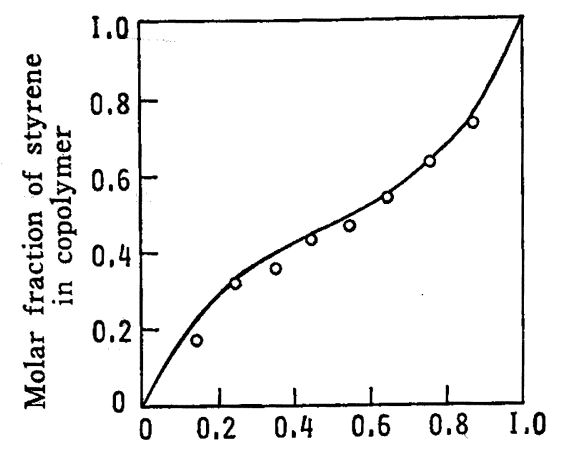

Molar fraction of styrene in monomer

Fig. 5 Copolymer composition curve for the copolymerization of styrene and MMA by cobalt(II) complexes with $\mathrm{CN}$ and acac mixed ligands

$\mathrm{Co}(\mathrm{II})=1.5 \times 10^{-4} \mathrm{~mol}$, Ratio of $\mathrm{Co} / \mathrm{CN} / \mathrm{acac}=1: 3: 2$, Monomer (styrene $+\mathrm{MMA})=10 \mathrm{~cm}^{3}$, Solvent $\left(\mathrm{H}_{2} \mathrm{O}\right)$ $=10 \mathrm{~cm}^{3}$, Surfactant (Tween 80$)=4 \mathrm{wt} \%$ (based on the weight of monomer), Oxygen $=4 \mathrm{~cm}^{3}$, Atmosphere $=$ Hydrogen, Reaction temp. $=30^{\circ} \mathrm{C}$

$1: 3: 2$ の錯体はコバルト(II)イオンの配位座以上に配位子が 加えられており, 溶液中に存在する真の活性な化学種については 不明である。重合開始の活性種, 水素と酸素の作用, および界面 活性剂の役割とその種類, 濃度などの影響を明らかにするために 引きつづき検討中である。

（1979 年 2 月, 日本化学会北海道支部冬季研究発表会講演）

\title{
Polymerization of Methyl Methacrylate by Cobalt(II) Complexes with Cyanide and Acetylacetonate Mixed Ligands
}

\author{
Yoshio AraI, Hiroki Matsuda and Mitsunori Urasawa \\ Department of Industrial Chemistry, Kitami Institute of Technology; \\ Koen-machi, Kitami-shi 090 Japan
}

The polymerization of methyl methacrylate (MMA) by cobalt(II) complexes with cyanide and acetylacetonate (acac) mixed ligands in aqueous solution at $30^{\circ} \mathrm{C}$ was investigated. The polymerization of MMA was initiated by the complex, whose $\mathrm{Co} / \mathrm{CN} / \mathrm{acac}$ ratio being $1: 3: 2$, by the addition of a small amount of oxygen in the presence of non-ionic surface-active agent under nitrogen atmosphere. 2,2-Diphenyl-1-picrylhydrazyl and excess amount of oxygen interfered with this polymerization. The composition curve of the copolymerization of styrene with MMA by this initiator agreed with that of ordinary radical polymerization. It was considered on the basis of the above results that the polymerization of MMA by this initiator proceeded through a radical mechanism. 